\title{
Preoperative neutrophil-to-lymphocyte ratio may contribute to the prediction of postoperative infectious complications in patients with acute appendicitis: a retrospective study
}

Mikito Mori ${ }^{1 *} \mathbb{0}$, Kazuo Narushima ${ }^{1}$, Atsushi Hirano ${ }^{1}$, Yoshihiko Kano ${ }^{1}$, Fumihiro Chiba ${ }^{1}$, Yoshihiro Edamoto ${ }^{1}$ and Masahiro Yoshida ${ }^{2}$

\begin{abstract}
Background: Several studies have assessed various clinical variables to identify risk factors for postoperative complications in patients with acute appendicitis. However, few studies have focused on the relationships between systemic inflammatory variables and postoperative complications in patients with acute appendicitis. We investigated the relationships between postoperative complications and systemic inflammatory variables, and assessed the clinical utility of these variables as predictors of postoperative complications in patients with acute appendicitis.
\end{abstract}

Methods: We retrospectively reviewed 181 patients who underwent immediate appendectomy for acute appendicitis. All postoperative complications were classified as infectious or noninfectious, and we evaluated the relationships between postoperative complications and clinical factors including the preoperative neutrophil-to-lymphocyte ratio and platelet-to-lymphocyte ratio.

Results: In total, 28 patients (15.5\%) had postoperative Clavien-Dindo grade II-IV complications; 17 patients (9.4\%) and 11 patients (6.1\%) were categorized as the infectious and noninfectious complication groups, respectively. The cutoff value of the preoperative neutrophil-to-lymphocyte ratio for all complications was 11.3, and multivariate analysis revealed that the preoperative neutrophil-to-lymphocyte ratio was an independent predictor of any postoperative complication (odds ratio: 4.223, 95\% confidence interval: 1.335-13.352; $P=0.014$ ). The cutoff value of the preoperative neutrophil-to-lymphocyte ratio for infectious complications was 11.4 , and multivariate analysis revealed that the preoperative neutrophil-to-lymphocyte ratio was an independent predictor of infectious complications (odds ratio: $4.235,95 \%$ confidence interval: $1.137-15.776 ; P=0.031$ ).

Conclusions: In patients with acute appendicitis, the preoperative neutrophil-to-lymphocyte ratio may be a useful predictor of all postoperative complications, especially infectious complications.

Keywords: Acute appendicitis, Appendectomy, Neutrophils, Lymphocytes, Postoperative complications

*Correspondence: mikimori45@yahoo.co.jp

1 Department of Surgery, Secomedic Hospital, 696-1 Toyotomi-cho, Funabashi, Chiba 274-0053, Japan

Full list of author information is available at the end of the article

\section{Background}

Acute appendicitis is considered one of the most common diseases of the acute abdomen, with an estimated lifetime risk rate of $7-8 \%$ worldwide $[1,2]$. 
Acute appendicitis can be clinically and epidemiologically classified as uncomplicated or complicated acute appendicitis, and $70-80 \%$ of all patients with appendicitis are diagnosed with uncomplicated acute appendicitis [3]. Although some randomized clinical trials have demonstrated that antibiotic therapy for acute appendicitis may be feasible as an alternative to immediate appendectomy [4-10], immediate appendectomy is still the standard treatment for acute appendicitis. Appendectomy is a cardinal surgical procedure with low mortality but a postoperative complication rate of $5-28 \%[5,10-16]$. Several studies have suggested that clinical variables such as age, operation timing, type of surgery, and type of acute appendicitis are risk factors for postoperative complications [11-16].

The neutrophil-to-lymphocyte ratio (NLR) and platelet-to-lymphocyte ratio (PLR) are well-known systemic inflammatory variables related to the prognosis of colorectal, gastric, and pancreatic cancer [17-19]. Some recent studies suggest that systemic inflammatory variables may be useful for the prediction of postoperative complications in patients with various cancers [20-22]. However, few studies have focused on the relationships between systemic inflammatory variables and postoperative complications in patients with acute appendicitis. Therefore, we investigated the relationships between postoperative complications and systemic inflammatory variables, and assessed the clinical utility of these variables as predictors of postoperative complications in patients with acute appendicitis.

\section{Methods}

\section{Patients}

The study protocol was approved by the Institutional Review Board of our institution. We retrospectively reviewed the electronic medical records of 181 patients with acute appendicitis who underwent appendectomy within $48 \mathrm{~h}$ after hospital admission between January 2010 and August 2021 at Secomedic Hospital, Japan. The patient inclusion criteria were age $\geq 15$ years, emergency operation for acute appendicitis, and histologically confirmed diagnosis of acute appendicitis. We excluded patients who were pregnant, did not have histologically confirmed acute appendicitis, or underwent an interval appendectomy after initial antibiotic therapy. In this study, perforated appendicitis, gangrenous appendicitis, or appendicitis with a periappendiceal abscess was defined as complicated acute appendicitis; catarrhal or phlegmonous appendicitis was defined as uncomplicated acute appendicitis.

\section{Assessment of preoperative systemic inflammatory variables}

A routine blood examination was performed at the time of hospitalization. We assessed the preoperative white blood cell count ( $\mathrm{pWBC}$ ), platelet count (pPLT), serum C-reactive protein level (pCRP), NLR (pNLR), and PLR (pPLR) as representative systemic inflammatory variables. As previously reported, the NLR and PLR were calculated by dividing the neutrophil and platelet count, respectively, by the lymphocyte count [17-19].

\section{Visual assessment of acute appendicitis on computed tomography images}

In all patients, the maximum diameter of the appendix and the presence of fecalith, periappendiceal effusion, periappendiceal abscess, and ascites were evaluated on computed tomography (CT) images before surgery.

\section{Definitions of postoperative complications}

All complications occurring within 30 days after surgery were defined as postoperative complications and were graded using the Clavien-Dindo classification (C-D) system [23]. A diagnosis of postoperative intra-abdominal abscess, cholangitis, or paralytic ileus was based on the patient's symptoms, laboratory data, abdominal radiography, and CT findings. All postoperative complications were categorized as infectious or noninfectious.

\section{Statistical analysis}

The relationships between postoperative complications and systemic inflammatory variables were evaluated by the area under the curves (AUCs) of the receiver operating characteristic (ROC) curves. The cutoff values of continuous variables (including systemic inflammatory variables) were set at the point on the ROC curve closest to the $(0,1)$ point; these points corresponded to the optimal sensitivity and specificity yielding the minimal value for $(1 \text {-sensitivity })^{2}+(1 \text {-specificity })^{2}[24]$. The relationships between postoperative complications and type of appendectomy (open or laparoscopic) in patients with acute appendicitis were evaluated by Fisher's exact test. Univariate analyses of postoperative complications were performed using logistic regression to determine whether there were significant associations between the clinical factors and postoperative complications. Multivariate analysis was performed using logistic regression to determine the statistical significance of the clinical factors identified by univariate analysis. $P$ values $<0.05$ indicated statistical significance. $P$ values in multiple comparisons using Fisher's 
exact test were corrected using a false discovery rate. All statistical analyses were performed using SPSS for Windows (version 26.0; IBM Corp., Armonk, NY, USA).

Table 1 Characteristics of 181 patients with acute appendicitis

\begin{tabular}{|c|c|}
\hline Variable & $n=181$ \\
\hline Sex, male/female & $111 / 70$ \\
\hline Age, years & $44(15-92)$ \\
\hline $\mathrm{BMl}, \mathrm{kg} / \mathrm{m}^{2}$ & $21.8(15.6-33.6)$ \\
\hline ASA-PS classification, IE/IIE/IIIE & $72 / 103 / 6$ \\
\hline $\mathrm{pBT},{ }^{\circ} \mathrm{C}$ & $37.2(35.3-39.5)$ \\
\hline $\mathrm{pWBC}, \times 10^{9} / \mathrm{L}$ & $13.5(4.1-24.8)$ \\
\hline $\mathrm{pPLT}, \times 10^{9} / \mathrm{L}$ & $231(106-480)$ \\
\hline $\mathrm{pNTC}, \times 10^{9} / \mathrm{L}$ & $11.2(2.8-21.7)$ \\
\hline $\mathrm{pLPC}, \times 10^{9} / \mathrm{L}$ & $1.2(0.3-5.2)$ \\
\hline $\mathrm{pNLR}$ & $10.2(1.8-38.2)$ \\
\hline PPLR & $202.0(51.2-941.9)$ \\
\hline $\mathrm{pCRP}, \mathrm{mg} / \mathrm{L}$ & $47.6(0.1-334.7)$ \\
\hline Maximum diameter of the appendix, $\mathrm{mm}$ & $9.8(5.7-20.8)$ \\
\hline Fecalith $(+/-)$ & $95 / 86$ \\
\hline Periappendiceal effusion $(+/-)$ & $124 / 57$ \\
\hline Periappendiceal abscess $(+/-)$ & $13 / 168$ \\
\hline Ascites $(+/-)$ & $35 / 146$ \\
\hline Time to operation, $<6 / 6-12 / 13-24 / 25-48 \mathrm{~h}$ & $108 / 59 / 6 / 8$ \\
\hline Type of appendectomy, open/laparoscopic & $31 / 150$ \\
\hline Operative time, minutes & $50(23-160)$ \\
\hline Estimated blood loss, $\mathrm{mL}$ & $1(1-300)$ \\
\hline $\begin{array}{l}\text { Type of acute appendicitis, uncomplicated/compli- } \\
\text { cated }\end{array}$ & $93 / 88$ \\
\hline Postoperative complications, $C-D$ grade $\geq \|(+/-)$ & $28 / 153$ \\
\hline
\end{tabular}

Data are presented as $n$ or median (range). BMI, body mass index; ASA-PS, American Society of Anesthesiologists physical status; $\mathrm{pBT}$, preoperative body temperature; PWBC, preoperative white blood cell count; PPLT, preoperative platelet count; pNTC, preoperative neutrophil count; pLPC, preoperative lymphocyte count; $\mathrm{pNLR}$, preoperative neutrophil-to-lymphocyte ratio; $\mathrm{PPLR}$, preoperative platelet-to-lymphocyte ratio; $\mathrm{pCRP}$, preoperative C-reactive protein level, C-D, Clavien-Dindo classification

\section{Results}

Patient characteristics

The clinical characteristics of 181 patients (70 women, 111 men) with acute appendicitis who underwent immediate appendectomy are summarized in Table 1. Among 181 patients with acute appendicitis, 28 patients developed a postoperative complication classified as C-D grade II-IV.

\section{Relationships between postoperative complications and appendectomy type in patients with acute appendicitis}

Among 28 patients with $\mathrm{C}$-D grade $\geq$ II postoperative complications (15.5\%), 17 patients $(9.4 \%)$ were defined as the infectious complication group, including 11 patients with intra-abdominal abscess (6.1\%), four with wound infection $(2.2 \%)$, one with cholangitis $(0.6 \%)$, and one with enteritis $(0.6 \%)$. All 11 patients $(6.1 \%)$ in the noninfectious complication group had paralytic ileus. In the 'all complications' group and the infectious complications group, the incidence of complications significantly differed between patients who underwent open versus laparoscopic appendectomy $(P<0.001)$. In the infectious complication group, patients who underwent open appendectomy had a higher incidence of intra-abdominal abscess $(P<0.023)$ and wound infection $(P<0.001)$ than those who underwent laparoscopic appendectomy. In the noninfectious complication group, the incidence of paralytic ileus significantly differed between patients who underwent open versus laparoscopic appendectomy $(P=0.023)$ (Table 2$)$.

\section{Identification of useful predictors of all postoperative complications in patients with acute appendicitis}

Based on the ROC curves, the cutoff values of the pWBC, pPLT, pCRP, pNLR, and pPLR for all complications were set at $12.8 \times 10^{9} / \mathrm{L}, 254 \times 10^{9} / \mathrm{L}, 89.4 \mathrm{mg} / \mathrm{L}$,

Table 2 Relationships between postoperative complications and appendectomy type in patients with acute appendicitis

\begin{tabular}{|c|c|c|c|c|}
\hline $\mathrm{C}-\mathrm{D}$ grade $\geq \mathrm{II}$ & Total $n=181$ & Open appendectomy $\mathrm{n}=31$ & $\begin{array}{l}\text { Laparoscopic appendectomy } \\
n=150\end{array}$ & $p$ value $^{b}$ \\
\hline All complications & $28(15.5 \%)$ & $14(45.2 \%)$ & $14(9.3 \%)$ & $<0.001^{\mathrm{a}}$ \\
\hline Infectious complications & $17(9.4 \%)$ & $9(29.0 \%)$ & $8(5.3 \%)$ & $<0.001^{\mathrm{a}}$ \\
\hline Intra-abdominal abscess & $11(6.1 \%)$ & $5(16.1 \%)$ & $6(4.0 \%)$ & $0.023^{\mathrm{a}}$ \\
\hline Wound infection & $4(2.2 \%)$ & $4(12.9 \%)$ & $0(0.0 \%)$ & $<0.001^{\mathrm{a}}$ \\
\hline Cholangitis & $1(0.6 \%)$ & $0(0.0 \%)$ & $1(0.7 \%)$ & 1.000 \\
\hline Enteritis & $1(0.6 \%)$ & $0(0.0 \%)$ & $1(0.7 \%)$ & 1.000 \\
\hline Noninfectious complications & $11(6.1 \%)$ & $5(16.1 \%)$ & $6(4.0 \%)$ & $0.023^{\mathrm{a}}$ \\
\hline Paralytic ileus & $11(6.1 \%)$ & $5(16.1 \%)$ & $6(4.0 \%)$ & $0.023^{\mathrm{a}}$ \\
\hline
\end{tabular}

Data are presented as $\mathrm{n}(\%)$. C-D, Clavien-Dindo classification

${ }^{a}$ Statistically significant after false discovery rate correction. ${ }^{b}$ Fisher's exact test 

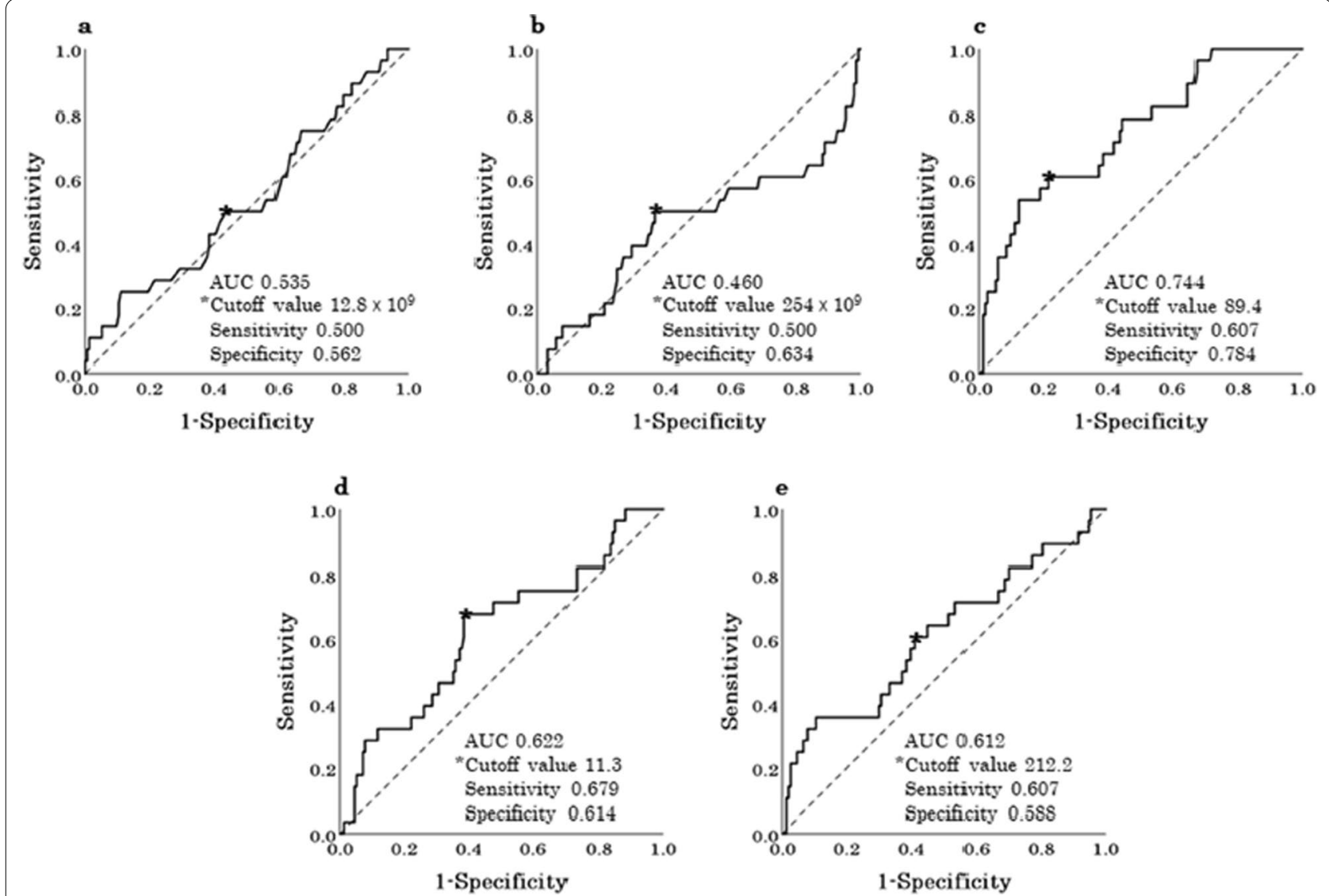

Fig. 1 Determination of the cutoff values of the systemic inflammatory variables for all postoperative complications using receiver operating characteristic curves. a pWBC, $\mathbf{b}$ pPLT, $\mathbf{c}$ pCRP, $\mathbf{d}$ pNLR, e $\mathrm{pPLR}$

11.3, and 212.2, respectively (Fig. 1). Of the 20 clinical factors assessed using univariate analysis, the variables significantly associated with all postoperative complications were age (odds ratio (OR), 4.856; 95\% confidence interval $(\mathrm{CI}) 2.003-11.772 ; P<0.001)$, body mass index (BMI) (OR, 2.590; 95\% CI 1.141-5.879; $P=0.023)$, American Society of Anesthesiologists physical status classification (OR, 2.486; 95\% CI 1.137-5.437; $P=0.023)$, preoperative body temperature $(\mathrm{OR}, 3.043$; 95\% CI 1.263-7.334; $P=0.013$ ), pNLR (OR, 3.363; 95\% CI 1.427-7.927; $P=0.006$ ), pCRP (OR, 5.409; 95\% CI $2.315-12.640 ; P<0.001)$, presence of periappendiceal effusion (OR, 4.545; 95\% CI, 1.312-15.748; $P=0.017$ ), presence of periappendiceal abscess (OR, 3.940; 95\% CI 1.186-13.093; $P=0.025$ ), presence of ascites (OR, 2.844; 95\% CI 1.175-6.884; $P=0.020)$, type of appendectomy (OR, 0.125; 95\% CI 0.051-0.306; $P<0.001$ ), operative time (OR, 8.195; 95\% CI 3.242-20.713; $P<0.001$ ), estimated blood loss (OR, 6.202; 95\% CI 2.622-14.672; $P<0.001$ ), and complicated acute appendicitis (OR,
8.344; $95 \%$ CI $2.760-25.221 ; P<0.001)$. Multivariate analysis of the significant factors identified using univariate analysis revealed that the independent risk factors for all postoperative complications were BMI (OR, 3.623; 95\% CI 1.116-11.757; $P=0.032$ ), pNLR (OR, 4.223; 95\% CI 1.335-13.352; $P=0.014)$, operative time (OR, 4.850; 95\% CI 1.410-16.682; $P=0.012)$, and complicated acute appendicitis (OR, 4.590; 95\% CI 1.004-20.972; $P=0.049)$ (Table 3).

\section{Identification of useful predictors of infectious complications in patients with acute appendicitis}

The cutoff values of the pWBC, pPLT, pCRP, pNLR, and pPLR for the infectious complication group were set at $13.8 \times 10^{9} / \mathrm{L}, 259 \times 10^{9} / \mathrm{L}, 146.6 \mathrm{mg} / \mathrm{L}, 11.4$, and 235.7 , respectively (Fig. 2). Univariate analysis showed that the variables significantly associated with infectious complications were age (OR, 4.160; 95\% CI 1.398-12.380; $P=0.010$ ), BMI (OR, 4.629; 95\% CI 1.553-13.795; $P=0.006$ ), pNLR (OR, 3.655; 95\% CI 1.230-10.863; 
Table 3 Relationships between all complications and clinical factors in patients with acute appendicitis

\begin{tabular}{|c|c|c|c|c|c|c|}
\hline \multirow[t]{2}{*}{ Variable } & \multicolumn{2}{|c|}{ All complications } & \multirow{2}{*}{$\begin{array}{l}\text { Univariate analysis } \\
\text { OR }(95 \% \mathrm{Cl})\end{array}$} & \multirow[t]{2}{*}{$p$ value $^{\mathrm{b}}$} & \multirow{2}{*}{$\begin{array}{l}\text { Multivariate analysis } \\
\text { OR }(95 \% \mathrm{Cl})\end{array}$} & \multirow[t]{2}{*}{$p$ value ${ }^{b}$} \\
\hline & + & - & & & & \\
\hline Sex, male/female & $18 / 10$ & $93 / 60$ & $0.861(0.372-1.991)$ & 0.727 & & \\
\hline Age $_{,}<49 / \geq 49$ years & $8 / 20$ & $101 / 52$ & $4.856(2.003-11.772)$ & $<0.001^{\mathrm{a}}$ & $3.672(0.743-18.134)$ & 0.110 \\
\hline $\mathrm{BMI},<23.1 / \geq 23.1 \mathrm{~kg} / \mathrm{m}^{2}$ & $12 / 16$ & $101 / 52$ & $2.590(1.141-5.879)$ & $0.023^{\mathrm{a}}$ & $3.623(1.116-11.757)$ & $0.032^{\mathrm{a}}$ \\
\hline ASA-PS classification, IE/IIE/IIIE & $5 / 22 / 1$ & $67 / 81 / 5$ & $2.486(1.137-5.437)$ & $0.023^{\mathrm{a}}$ & $0.387(0.080-1.864)$ & 0.236 \\
\hline $\mathrm{pBT},<37.3 / \geq 37.3^{\circ} \mathrm{C}$ & $8 / 20$ & $84 / 69$ & $3.043(1.263-7.334)$ & $0.013^{\mathrm{a}}$ & $2.351(0.732-7.545)$ & 0.151 \\
\hline$p W B C_{1}<12.8 / \geq 12.8 \times 10^{9} / \mathrm{L}$ & $14 / 14$ & $67 / 86$ & $0.779(0.348-1.746)$ & 0.544 & & \\
\hline $\mathrm{pPLT},<254 / \geq 254 \times 10^{9} / \mathrm{L}$ & $14 / 14$ & $96 / 57$ & $1.684(0.749-3.786)$ & 0.207 & & \\
\hline $\mathrm{pNLR},<11.3 / \geq 11.3$ & $9 / 19$ & $94 / 59$ & $3.363(1.427-7.927)$ & $0.006^{\mathrm{a}}$ & $4.223(1.335-13.352)$ & $0.014^{\mathrm{a}}$ \\
\hline $\mathrm{pPLR},<212.2 / \geq 212.2$ & $11 / 17$ & $89 / 64$ & $2.149(0.943-4.897)$ & 0.069 & & \\
\hline $\mathrm{pCRP},<89.4 / \geq 89.4 \mathrm{mg} / \mathrm{L}$ & $11 / 17$ & $119 / 34$ & $5.409(2.315-12.640)$ & $<0.001^{\mathrm{a}}$ & $1.108(0.346-3.551)$ & 0.863 \\
\hline Maximum diameter of the appendix, $<10.0 / \geq 10.0 \mathrm{~mm}$ & 10/18 & $82 / 71$ & $2.079(0.901-4.795)$ & 0.086 & & \\
\hline Fecalith $(+/-)$ & $18 / 10$ & $77 / 76$ & $1.777(0.770-4.097)$ & 0.178 & & \\
\hline Periappendiceal effusion (+/-) & $25 / 3$ & $99 / 54$ & $4.545(1.312-15.748)$ & $0.017^{\mathrm{a}}$ & $0.345(0.053-2.252)$ & 0.266 \\
\hline Periappendiceal abscess $(+/-)$ & $5 / 23$ & $8 / 145$ & $3.940(1.186-13.093)$ & $0.025^{\mathrm{a}}$ & $1.453(0.264-7.989)$ & 0.667 \\
\hline Ascites $(+/-)$ & $10 / 18$ & $25 / 128$ & $2.844(1.175-6.884)$ & $0.020^{\mathrm{a}}$ & $2.121(0.607-7.411)$ & 0.239 \\
\hline Time to operation, $<6 / 6-12 / 13-24 / 25-48 \mathrm{~h}$ & 17/10/0/1 & $91 / 49 / 6 / 7$ & $0.877(0.501-1.538)$ & 0.648 & & \\
\hline Type of appendectomy, open/laparoscopic & $14 / 14$ & $17 / 136$ & $0.125(0.051-0.306)$ & $<0.001^{\mathrm{a}}$ & $0.691(0.055-8.744)$ & 0.776 \\
\hline Operative time, $<60 / \geq 60 \mathrm{~min}$ & $7 / 21$ & $112 / 41$ & $8.195(3.242-20.713)$ & $<0.001^{\mathrm{a}}$ & $4.850(1.410-16.682)$ & $0.012^{\mathrm{a}}$ \\
\hline Estimated blood loss, $<3 / \geq 3 \mathrm{~mL}$ & $13 / 15$ & $129 / 24$ & $6.202(2.622-14.672)$ & $<0.001^{\mathrm{a}}$ & $1.590(0.126-20.000)$ & 0.720 \\
\hline Type of acute appendicitis, uncomplicated/complicated & $4 / 24$ & $89 / 64$ & $8.344(2.760-25.221)$ & $<0.001^{\mathrm{a}}$ & $4.590(1.004-20.972)$ & $0.049^{\mathrm{a}}$ \\
\hline
\end{tabular}

\section{Data are presented as $n$}

BMI, body mass index; ASA-PS, American Society of Anesthesiologists physical status; pBT, preoperative body temperature; pWBC, preoperative white blood cell count; pPLT, preoperative platelet count; $\mathrm{PNLR}$, preoperative neutrophil-to-lymphocyte ratio; $\mathrm{pPLR}$, preoperative platelet-to-lymphocyte ratio; pCRP, preoperative C-reactive protein level; $\mathrm{OR}$, odds ratio; $\mathrm{Cl}$, confidence interval

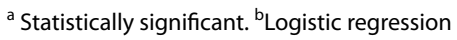

$P=0.020)$, pCRP $(\mathrm{OR}, 6.255 ; 95 \%$ CI $2.204-17.754$ $P=0.001)$, type of appendectomy (OR, $0.138 ; 95 \% \mathrm{CI}$ $0.048-0.395 ; P<0.001)$, operative time (OR, 7.628; $95 \%$ CI 2.369-24.563; $P=0.001)$, estimated blood loss (OR, 6.650; 95\% CI 2.337-18.926; $P<0.001)$, and complicated acute appendicitis (OR, 5.676; 95\% CI 1.571-20.502; $P=0.008$ ). Multivariate analysis of the significant factors identified using univariate analysis revealed that the independent risk factors for infectious complications were BMI (OR, 4.471; 95\% CI 1.275-15.676; $P=0.019$ ) and pNLR (OR, 4.235; 95\% CI 1.137-15.776; $P=0.031$ ) (Table 4).

\section{Identification of useful predictors of noninfectious complications in patients with acute appendicitis}

The cutoff values of the pWBC, pPLT, pCRP, pNLR, and pPLR for the noninfectious complication group were set at $9.6 \times 10^{9} / \mathrm{L}, 188 \times 10^{9} / \mathrm{L}, 89.4 \mathrm{mg} / \mathrm{L}, 11.3$, and 212.2 , respectively (Fig. 3). Univariate analysis showed that the variables significantly associated with noninfectious complications were age (OR, 5.149; 95\% CI 1.316-20.149;
$P=0.019$ ), preoperative body temperature (OR, 5.062; 95\% CI 1.062-24.128; $P=0.042)$, pWBC (OR, 0.151; 95\% CI 0.042-0.543; $P=0.004$ ), pCRP (OR, 7.876; 95\% CI 1.999-31.033; $P=0.003$ ), presence of fecalith (OR, 10.000 ; $95 \%$ CI 1.252-79.845; $P=0.030)$, presence of periappendiceal abscess (OR, 6.000; 95\% CI 1.376-26.166; $P=0.017$ ), presence of ascites (OR, 3.889; 95\% CI 1.11413.582; $P=0.033$ ), type of appendectomy (OR, 0.217; 95\% CI $0.062-0.762 ; P=0.017$ ), operative time (OR, 7.265; 95\% CI 2.008-26.285; $P=0.003$ ), and complicated acute appendicitis (OR, 11.795; 95\% CI 1.477-94.190; $P=0.020$ ). Multivariate analysis of the significant factors identified using univariate analysis revealed that the only independent risk factor for noninfectious complications was the pWBC (OR, 0.125; 95\% CI 0.021-0.729; $P=0.021$ ) (Table 5).

\section{Discussion}

We assessed the relationships between systemic inflammatory variables and postoperative complications after immediate appendectomy. An increased pNLR was 

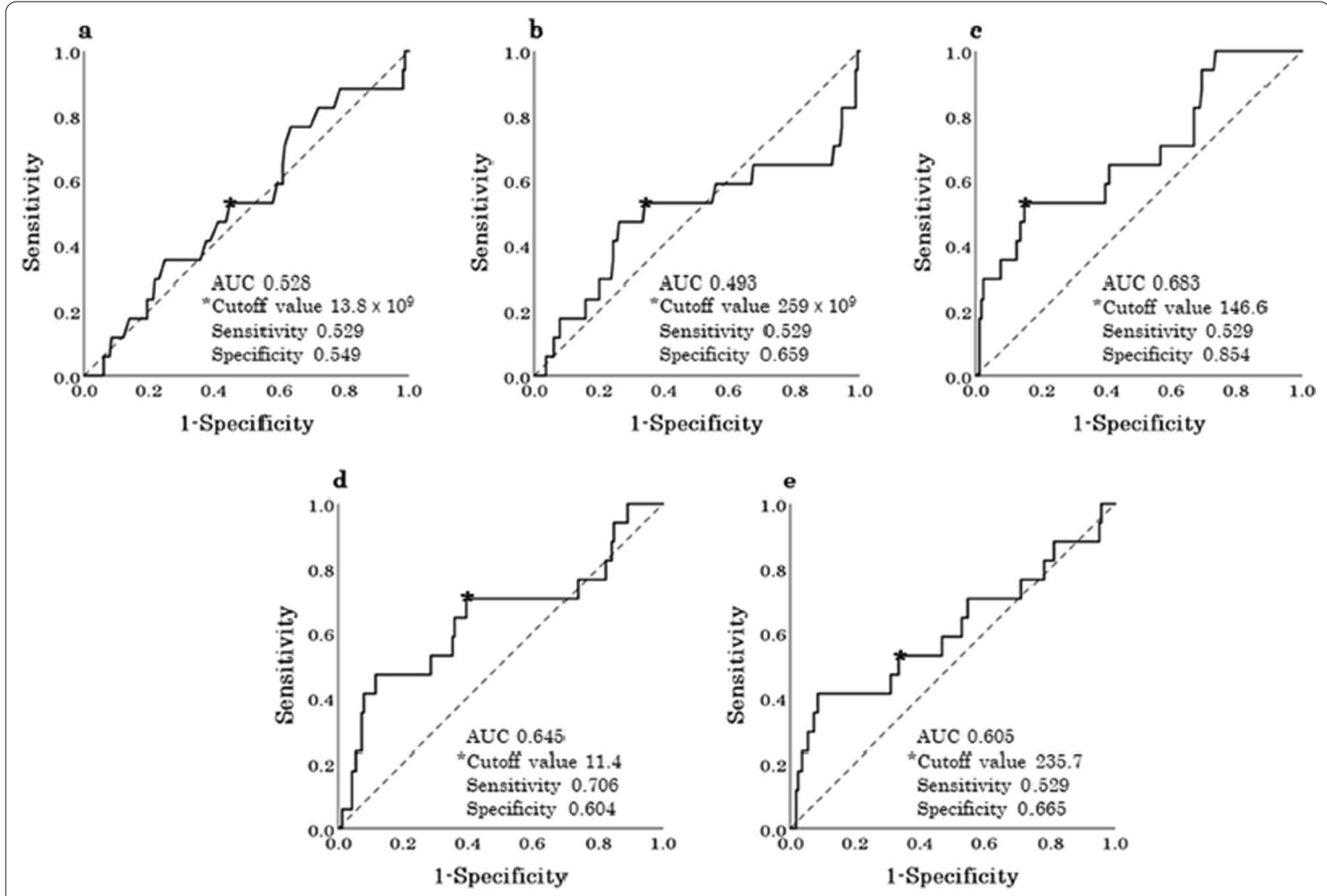

Fig. 2 Determination of the cutoff values of the systemic inflammatory variables for infectious complications using receiver operating characteristic curves. a pWBC, b pPLT, $\mathbf{c} p C R P, \mathbf{d} p N L R$, e $p P L R$

identified as an independent risk factor for all postoperative complications, especially infectious complications, in patients with acute appendicitis.

Although recent accumulating evidence suggests that early surgical intervention may not always be required for acute appendicitis because of the relatively high success rate of antibiotic therapy [4-10], some studies have suggested that nonoperative management with antibiotics is not always effective in patients with acute appendicitis with a high serum CRP level, presence of an appendicolith, large appendiceal diameter, or complicated acute appendicitis [25-27]. Therefore, immediate appendectomy is considered the main treatment for acute appendicitis.

Several studies have identified various clinical variables, including older age, delayed or night operation, longer operative time, open surgery, and complicated acute appendicitis, as risk factors of postoperative complications such as wound infection, intra-abdominal abscess, and prolonged ileus [11-16]. Segev et al. [15] demonstrated that the rate of postoperative complications was higher in older adult patients with a longer delay from symptom onset to admission or from admission to surgery, complicated acute appendicitis, and a longer operative time. Regarding the optimal operation timing, some studies have suggested that delayed appendectomy may be unsafe or ineffective for adult patients with complicated acute appendicitis [11, 13-15]. In contrast, other studies have reported that delayed appendectomy is not associated with an increase in the occurrence of postoperative complications [16, 28, 29]. Laparoscopic appendectomy has become the main surgical treatment for acute appendicitis, and several studies have reported that laparoscopic appendectomy is the most effective surgical treatment for acute appendicitis and is associated with a lower incidence of postoperative complications, shorter hospital stay, and better quality-of-life scores compared with open appendectomy [30-32]. The incidence of postoperative complications after immediate appendectomy for uncomplicated acute appendicitis is generally $10-19 \%$. 
Table 4 Relationships between infectious complications and clinical factors in patients with acute appendicitis

\begin{tabular}{|c|c|c|c|c|c|c|}
\hline \multirow[t]{2}{*}{ Variable } & \multicolumn{2}{|c|}{ All complications } & \multirow{2}{*}{$\begin{array}{l}\text { Univariate analysis } \\
\text { OR }(95 \% \mathrm{Cl})\end{array}$} & \multirow[t]{2}{*}{$p$ value $^{\mathrm{b}}$} & \multirow{2}{*}{$\begin{array}{l}\text { Multivariate analysis } \\
\text { OR }(95 \% \mathrm{Cl})\end{array}$} & \multirow[t]{2}{*}{$p$ value ${ }^{b}$} \\
\hline & + & - & & & & \\
\hline Sex, male/female & $7 / 10$ & $63 / 101$ & $1.122(0.406-3.099)$ & 0.824 & & \\
\hline Age $_{,}<49 / \geq 49$ years & $5 / 12$ & $104 / 60$ & $4.160(1.398-12.380)$ & $0.010^{\mathrm{a}}$ & $1.210(0.315-4.648)$ & 0.782 \\
\hline $\mathrm{BMI},<23.1 / \geq 23.1 \mathrm{~kg} / \mathrm{m}^{2}$ & $5 / 12$ & $108 / 56$ & $4.629(1.553-13.795)$ & $0.006^{\mathrm{a}}$ & $4.471(1.275-15.676)$ & $0.019^{\mathrm{a}}$ \\
\hline ASA-PS classification, IE/IIE/IIIE & $3 / 14 / 0$ & 69/89/6 & $2.027(0.793-5.185)$ & 0.140 & & \\
\hline $\mathrm{pBT},<37.3 / \geq 37.3^{\circ} \mathrm{C}$ & $6 / 11$ & $86 / 78$ & $2.021(0.714-5.724)$ & 0.185 & & \\
\hline $\mathrm{pWBC},<13.8 / \geq 13.8 \times 10^{9} / \mathrm{L}$ & $8 / 9$ & $86 / 78$ & $1.240(0.456-3.373)$ & 0.673 & & \\
\hline $\mathrm{pPLT},<259 / \geq 259 \times 10^{9} / \mathrm{L}$ & $8 / 9$ & $107 / 57$ & $2.112(0.773-5.770)$ & 0.145 & & \\
\hline $\mathrm{pNLR},<11.4 / \geq 11.4$ & $5 / 12$ & $99 / 65$ & $3.655(1.230-10.863)$ & $0.020^{\mathrm{a}}$ & $4.235(1.137-15.776)$ & $0.031^{\mathrm{a}}$ \\
\hline $\mathrm{pPLR},<235.7 / \geq 235.7$ & $8 / 9$ & $108 / 56$ & $2.170(0.794-5.931)$ & 0.131 & & \\
\hline $\mathrm{pCRP},<146.6 / \geq 146.6 \mathrm{mg} / \mathrm{L}$ & $8 / 9$ & $139 / 25$ & $6.255(2.204-17.754)$ & $0.001^{\mathrm{a}}$ & $2.160(0.532-8.777)$ & 0.282 \\
\hline Maximum diameter of the appendix, $<9.4 / \geq 9.4 \mathrm{~mm}$ & $3 / 14$ & $68 / 96$ & $3.306(0.914-11.949)$ & 0.068 & & \\
\hline Fecalith $(+/-)$ & $8 / 9$ & $87 / 77$ & $0.787(0.289-2.140)$ & 0.638 & & \\
\hline Periappendiceal effusion (+/-) & $15 / 2$ & $109 / 55$ & $3.784(0.836-17.141)$ & 0.084 & & \\
\hline Periappendiceal abscess $(+/-)$ & $2 / 15$ & $11 / 153$ & $1.855(0.375-9.160)$ & 0.449 & & \\
\hline Ascites $(+/-)$ & $5 / 12$ & $30 / 134$ & $1.861(0.610-5.680)$ & 0.275 & & \\
\hline Time to operation, $<6 / 6-12 / 13-24 / 25-48 \mathrm{~h}$ & $11 / 6 / 0 / 0$ & $97 / 53 / 6 / 8$ & $0.669(0.297-1.510)$ & 0.334 & & \\
\hline Type of appendectomy, open/laparoscopic & $9 / 8$ & $22 / 142$ & $0.138(0.048-0.395)$ & $<0.001^{\mathrm{a}}$ & $1.588(0.127-19.912)$ & 0.720 \\
\hline Operative time, $<60 / \geq 60 \mathrm{~min}$ & $4 / 13$ & $115 / 49$ & $7.628(2.369-24.563)$ & $0.001^{\mathrm{a}}$ & $3.704(0.854-16.066)$ & 0.080 \\
\hline Estimated blood loss, $<3 / \geq 3 \mathrm{~mL}$ & $7 / 10$ & $135 / 29$ & $6.650(2.337-18.926)$ & $<0.001^{\mathrm{a}}$ & $3.924(0.324-47.571)$ & 0.283 \\
\hline Type of acute appendicitis, uncomplicated/complicated & $3 / 14$ & $90 / 74$ & $5.676(1.571-20.502)$ & $0.008^{\mathrm{a}}$ & $1.583(0.331-7.570)$ & 0.565 \\
\hline
\end{tabular}

\section{Data are presented as $n$}

BMI, body mass index; ASA-PS, American Society of Anesthesiologists physical status; pBT, preoperative body temperature; pWBC, preoperative white blood cell count; $\mathrm{pPLT}$, preoperative platelet count; pNLR, preoperative neutrophil-to-lymphocyte ratio; pPLR, preoperative platelet-to-lymphocyte ratio; $\mathrm{pCRP}$, preoperative C-reactive protein level; $\mathrm{OR}$, odds ratio; $\mathrm{Cl}$, confidence interval

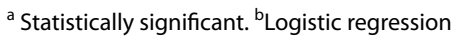

However, the incidence of postoperative complications after immediate appendectomy for complicated acute appendicitis increases to $30 \%$, and some studies have proposed that antibiotic therapy, percutaneous drainage, or interval appendectomy may have some advantages over immediate appendectomy for complicated acute appendicitis [33, 34]. In our study, the incidence of any postoperative complication was $15.5 \%$; this is slightly higher than the incidence reported in previous studies because $48.6 \%$ of our patients were diagnosed with complicated acute appendicitis, which may affect the incidence of postoperative complications. As seen in previous studies, our results showed a significant association between postoperative complications and operative time or complicated acute appendicitis; however, we found no significant association between postoperative complications and age, operation timing, or open appendectomy.

Increased leukocyte and platelet counts are usually observed in the systemic inflammatory response. Neutrophils are the predominant leukocyte subset that is recruited to inflamed tissue by the initial innate immune system response [35], and platelets serve as a major contributor of several pro-inflammatory chemokines and possess a whole inventory of surface receptors and adhesion molecules that enable platelets to bind to leukocytes, circulating pathogens, and bacteria [36]. To our knowledge, ours is the first study to demonstrate that the pNLR is a useful predictor of postoperative infectious complications in patients with acute appendicitis. An increased pNLR indicates both a heightened neutrophil-dependent inflammatory response and a decreased lymphocytemediated antibacterial immune reaction, which may affect the development of postoperative infectious complications. Therefore, postoperative infectious complications in acute appendicitis patients with an increased NLR may be reduced by a combination of perioperative antimicrobial treatment (using broad-spectrum antibiotics) and anti-inflammatory therapy with immediate appendectomy, or nonsurgical treatment with antibiotics substituted for immediate appendectomy. 

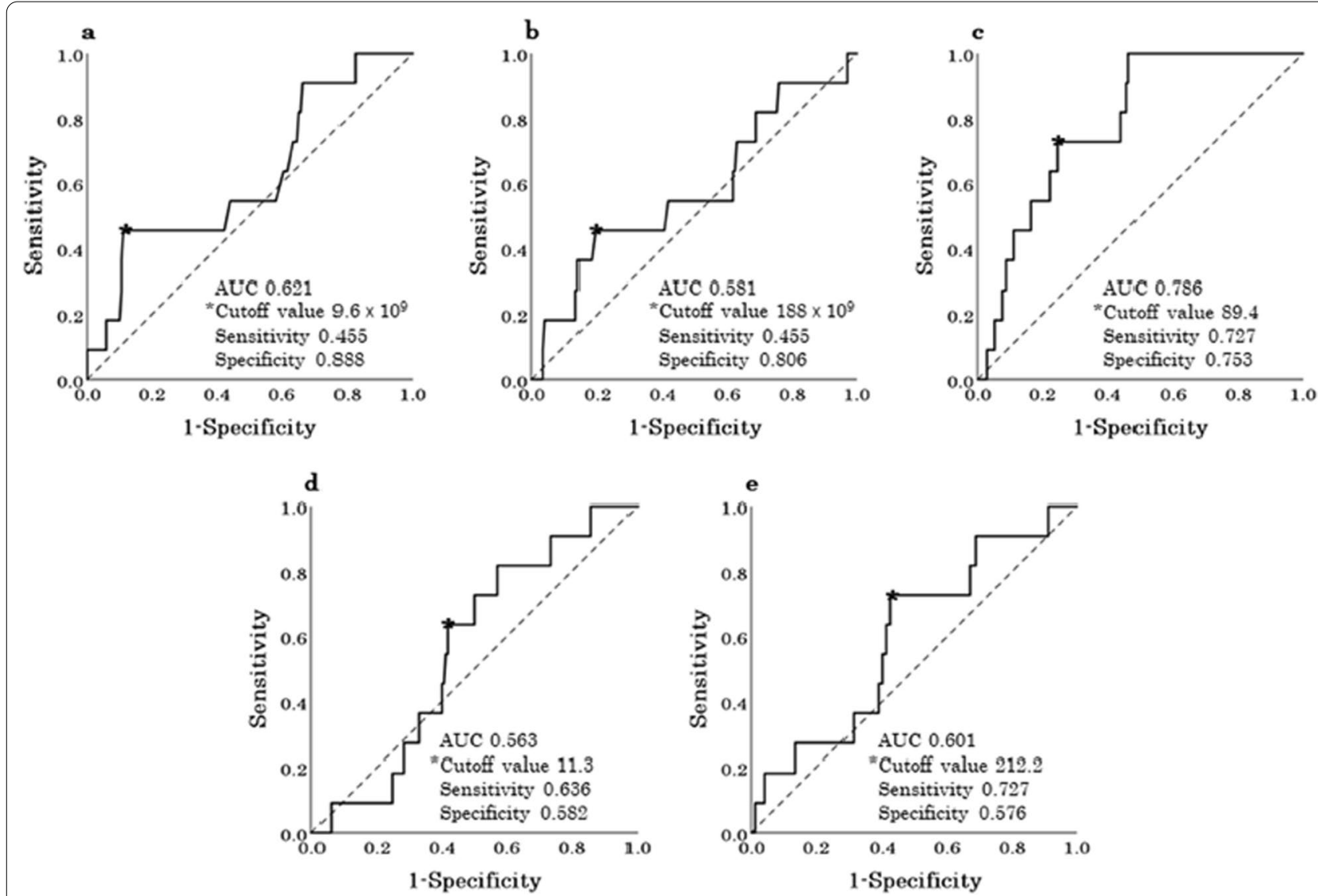

Fig. 3 Determination of the cutoff values of the systemic inflammatory variables for noninfectious complications using receiver operating characteristic curves. a pWBC, b pPLT, c pCRP, d pNLR, e pPLR

Our study has limitations. Because this was a retrospective study conducted in a single institution with a small sample size and patient selection bias, there were differences in patients' characteristics, which may have led to biased estimates of postoperative complications. Moreover, it is difficult to precisely diagnose other complications with different severities. Although our findings should be interpreted with caution, we believe that their potential clinical significance justifies further investigation.

\section{Conclusions}

Our study demonstrated that the pNLR was the most useful predictor of postoperative complications, especially infectious complications, after immediate appendectomy for acute appendicitis. Although further investigation is required to verify the utility of the pNLR as a predictor of infectious complications after immediate appendectomy for acute appendicitis, a high NLR in patients with acute appendicitis before appendectomy may contribute to the prediction or prevention of postoperative infectious complications. 
Table 5 Relationships between noninfectious complications and clinical factors in patients with acute appendicitis

\begin{tabular}{|c|c|c|c|c|c|c|}
\hline \multirow[t]{2}{*}{ Variable } & \multicolumn{2}{|c|}{ All complications } & \multirow{2}{*}{$\begin{array}{l}\text { Univariate analysis } \\
\text { OR }(95 \% \mathrm{Cl})\end{array}$} & \multirow[t]{2}{*}{$p$ value $^{b}$} & \multirow{2}{*}{$\begin{array}{l}\text { Multivariate analysis } \\
\text { OR }(95 \% \mathrm{Cl})\end{array}$} & \multirow[t]{2}{*}{$p$ value $^{\mathrm{b}}$} \\
\hline & + & - & & & & \\
\hline Sex, male/female & $8 / 3$ & $103 / 67$ & $0.576(0.148-2.251)$ & 0.428 & & \\
\hline 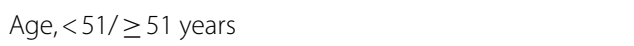 & $3 / 8$ & $112 / 58$ & $5.149(1.316-20.149)$ & $0.019^{\mathrm{a}}$ & $2.157(0.343-13.563)$ & 0.413 \\
\hline $\mathrm{BMI}_{,}<21.4 / \geq 21.4 \mathrm{~kg} / \mathrm{m}^{2}$ & $6 / 5$ & $75 / 95$ & $0.658(0.193-2.239)$ & 0.503 & & \\
\hline ASA-PS classification, IE/IIE/IIIE & $2 / 8 / 1$ & $70 / 95 / 5$ & $2.732(0.848-8.803)$ & 0.092 & & \\
\hline $\mathrm{pBT},<37.3 / \geq 37.3^{\circ} \mathrm{C}$ & $2 / 9$ & $90 / 80$ & $5.062(1.062-24.128)$ & $0.042^{\mathrm{a}}$ & $4.100(0.646-26.016)$ & 0.134 \\
\hline$p W B C_{1}<9.6 / \geq 9.6 \times 10^{9} / \mathrm{L}$ & $5 / 6$ & $19 / 151$ & $0.151(0.042-0.543)$ & $0.004^{\mathrm{a}}$ & $0.125(0.021-0.729)$ & $0.021^{\mathrm{a}}$ \\
\hline $\mathrm{pPLT},<188 / \geq 188 \times 10^{9} / \mathrm{L}$ & $5 / 6$ & $33 / 137$ & $0.289(0.083-1.005)$ & 0.051 & & \\
\hline $\mathrm{pNLR},<11.3 / \geq 11.3$ & $4 / 7$ & $99 / 71$ & $2.440(0.688-8.652)$ & 0.167 & & \\
\hline $\mathrm{pPLR},<212.2 / \geq 212.2$ & $3 / 8$ & $97 / 73$ & $3.543(0.908-13.822)$ & 0.069 & & \\
\hline $\mathrm{pCRP},<89.4 / \geq 89.4 \mathrm{mg} / \mathrm{L}$ & $3 / 8$ & $127 / 43$ & $7.876(1.999-31.033)$ & $0.003^{\mathrm{a}}$ & $3.065(0.476-19.740)$ & 0.239 \\
\hline Maximum diameter of the appendix,$<10.0 / \geq 10.0 \mathrm{~mm}$ & $3 / 8$ & $89 / 81$ & $2.930(0.752-11.423)$ & 0.121 & & \\
\hline Fecalith $(+/-)$ & $10 / 1$ & $85 / 85$ & $10.000(1.252-79.845)$ & $0.030^{\mathrm{a}}$ & $7.950(0.712-88.792)$ & 0.092 \\
\hline Periappendiceal effusion $(+/-)$ & $10 / 1$ & $114 / 56$ & $4.912(0.613-39.334)$ & 0.134 & & \\
\hline Periappendiceal abscess $(+/-)$ & $3 / 8$ & $10 / 160$ & $6.000(1.376-26.166)$ & $0.017^{\mathrm{a}}$ & $2.617(0.335-20.441)$ & 0.359 \\
\hline Ascites $(+/-)$ & $5 / 6$ & $30 / 140$ & $3.889(1.114-13.582)$ & $0.033^{\mathrm{a}}$ & $2.013(0.397-10.200)$ & 0.398 \\
\hline Time to operation, $<6 / 6-12 / 13-24 / 25-48 \mathrm{~h}$ & $6 / 4 / 0 / 1$ & $102 / 55 / 6 / 7$ & $1.203(0.582-2.487)$ & 0.618 & & \\
\hline Type of appendectomy, open/laparoscopic & $5 / 6$ & $26 / 144$ & $0.217(0.062-0.762)$ & $0.017^{\mathrm{a}}$ & $0.932(0.140-6.205)$ & 0.942 \\
\hline Operative time, $<69 / \geq 69 \mathrm{~min}$ & $4 / 7$ & $137 / 33$ & $7.265(2.008-26.285)$ & $0.003^{\mathrm{a}}$ & $1.884(0.301-11.299)$ & 0.508 \\
\hline Estimated blood loss, $<2 / \geq 2 \mathrm{~mL}$ & $6 / 5$ & $135 / 35$ & $3.214(0.927-11.148)$ & 0.066 & & \\
\hline Type of acute appendicitis, uncomplicated/complicated & $1 / 10$ & $92 / 78$ & $11.795(1.477-94.190)$ & $0.020^{\mathrm{a}}$ & $1.877(0.142-24.868)$ & 0.633 \\
\hline
\end{tabular}

\section{Data are presented as $n$}

BMI, body mass index; ASA-PS, American Society of Anesthesiologists physical status; pBT, preoperative body temperature; pWBC, preoperative white blood cell count; pPLT, preoperative platelet count; pNLR, preoperative neutrophil-to-lymphocyte ratio; pPLR, preoperative platelet-to-lymphocyte ratio; pCRP, preoperative C-reactive protein level; $\mathrm{OR}$, odds ratio; $\mathrm{Cl}$, confidence interval

a Statistically significant. ${ }^{\mathrm{b}}$ Logistic regression

\section{Abbreviations}

NLR: Neutrophil-to-lymphocyte ratio; PLR: Platelet-to-lymphocyte ratio; pWBC: Preoperative white blood cell count; pPLT: Preoperative platelet count; pCRP: Preoperative serum C-reactive protein level; CT: Computed tomography; C-D: Clavien-Dindo classification; ROC: Receiver operating characteristics; AUC: Area under the ROC curve; OR: Odds ratio; Cl: Confidence interval; BMI: Body mass index.

\section{Acknowledgements}

We thank Kelly Zammit, BVSc, from Edanz (https://jp.edanz.com/ac), for editing a draft of this manuscript.

\section{Authors' contributions}

$\mathrm{KN}, \mathrm{YE}$, and MM collected the data. AH, FC, and YK performed the statistical analysis. MM, KN, and MY drafted the manuscript. All authors read and approved the final manuscript.

\section{Funding}

Not applicable.

\section{Availability of data and materials}

The datasets used and/or analyzed during the current study are available from the corresponding author upon reasonable request.

\section{Declarations}

\section{Ethics approval and consent to participate}

The study was conducted in accordance with the principals of the Declaration of Helsinki. Secomedic Hospital Ethics Review Board approved the retrospective data collection and analysis (Reference Number: 2021-001). All patients gave written informed consent for the collection of their medical data for scientific purposes.

\section{Consent for publication}

Not applicable.

\section{Competing interests}

The authors declare that they have no competing interests.

\section{Author details}

${ }^{1}$ Department of Surgery, Secomedic Hospital, 696-1 Toyotomi-cho, Funabashi, Chiba 274-0053, Japan. ${ }^{2}$ Department of Hepato-Biliary-Pancreatic and Gastrointestinal Surgery, International University of Health and Welfare Ichikawa Hospital, 6-1-14 Kounodai, Ichikawa, Chiba 272-0827, Japan.

Received: 15 December 2021 Accepted: 24 February 2022

Published online: 03 March 2022

\section{References}

1. Stewart B, Khanduri P, McCord C, Ohene-Yeboah M, Uranues S, Vega Rivera F, et al. Global disease burden of conditions requiring emergency surgery. Br J Surg. 2014;101:e9-22.

2. Bhangu A, Søreide K, Di Saverio S, Assarsson JH, Drake FT. Acute appendicitis: modern understanding of pathogenesis, diagnosis, and management. Lancet. 2015;386:1278-87.

3. Mällinen J, Vaarala S, Mäkinen M, Lietzén E, Grönroos J, Ohtonen P, et al. Appendicolith appendicitis is clinically complicated acute appendicitis-is 
it histopathologically different from uncomplicated acute appendicitis. Int J Colorectal Dis. 2019;34:1393-400.

4. Oliak D, Yamini D, Udani VM, Lewis RJ, Vargas H, Arnell T, et al. Nonoperative management of perforated appendicitis without periappendiceal mass. Am J Surg. 2000;179:177-81.

5. Styrud J, Eriksson S, Nilsson I, Ahlberg G, Haapaniemi S, Neovius G, et al. Appendectomy versus antibiotic treatment in acute appendicitis. A prospective multicenter randomized controlled trial. World J Surg. 2006;30:1033-7.

6. Hansson J, Körner U, Khorram-Manesh A, Solberg A, Lundholm K. Randomized clinical trial of antibiotic therapy versus appendectomy as primary treatment of acute appendicitis in unselected patients. Br I Surg. 2009:96:473-81.

7. Vons C, Barry C, Maitre S, Pautrat K, Leconte M, Costaglioli B, et al. Amoxicillin plus clavulanic acid versus appendicectomy for treatment of acute uncomplicated appendicitis: an open-label, non-inferiority, randomized controlled trial. Lancet. 2011;377:1573-9.

8. Di Saverio S, Sibilio A, Giorgini E, Biscardi A, Villani S, Coccolini F, et al. The NOTA study (Non Operative Treatment for Acute Appendicitis): prospective study on the efficacy and safety of antibiotics (amoxicillin and clavulanic acid) for treating patients with right lower quadrant abdominal pain and long-term follow-up of conservatively treated suspected appendicitis. Ann Surg. 2014;260:109-17.

9. Salminen P, Paajanen H, Rautio T, Nordström P, Aarnio M, Rantanen T, et al. Antibiotic therapy vs appendectomy for treatment of uncomplicated acute appendicitis: the APPAC randomized clinical trial. JAMA. 2015:313:2340-8.

10. Sallinen V, AkI EA, You JJ, Agarwal A, Shoucair S, Vandvik PO, et al. Metaanalysis of antibiotics versus appendectomy for non-perforated acute appendicitis. Br J Surg. 2016;103:656-67. https://doi.org/10.1002/bjs. 10147.

11. Kraemer M, Franke C, Ohmann C, Yang Q, Acute Abdominal Pain Study Group. Acute appendicitis in late adulthood: incidence, presentation, and outcome. Result of a prospective multicenter acute abdominal pain study and a review of the literature. Langenbecks Arch Surg. 2000;385:470-81.

12. Margenthaler JA, Longo WE, Virgo KS, Johnson FE, Oprian CA, Henderson WG, et al. Risk factors for adverse outcomes after the surgical treatment of appendicitis in adults. Ann Surg. 2003;238:59-66.

13. Ditillo MF, Dziura JD, Rabinovici R. Is it safe to delay appendectomy in adults with acute appendicitis? Ann Surg. 2006;244:656-60.

14. Kelz RR, Freeman KM, Hosokawa PW, Asch DA, Spitz FR, Moskowitz M, et al. Time of day is associated with postoperative morbidity: analysis of the national surgical quality improvement program data. Ann Surg. 2008;247:544-52.

15. Segev L, Keidar A, Schrier I, Rayman S, Wasserberg N, Sadot E. Acute appendicitis in the elderly in the twenty-first century. J Gastrointest Surg. 2015;19:730-5.

16. Andert A, Alizai HP, Klink CD, Neitzke N, Fitzner C, Heidenhain C, et al. Risk factors for morbidity after appendectomy. Langenbecks Arch Surg. 2017:402:987-93.

17. Chen JH, Zhai ET, Yuan YJ, Wu KM, Xu JB, Peng JJ, et al. Systemic immuneinflammation index for predicting prognosis of colorectal cancer. World J Gastroenterol. 2017;23:6261-72.

18. Song W, Tian C, Wang K, Zhang RJ, Zou SB. Preoperative platelet lymphocyte ratio as independent predictors of prognosis in pancreatic cancer: a systematic review and meta-analysis. PLoS One. 2017;12:e0178762.

19. Mori M, Shuto K, Kosugi C, Narushima K, Hayashi H, Matsubara H, et al. An increase in the neutrophil-to-lymphocyte ratio during adjuvant chemotherapy indicates a poor prognosis in patients with stage II or III gastric cancer. BMC Cancer. 2018;18:1-8.

20. Lan H, Zhou L, Chi D, Zhou Q, Tang X, Zhu D, et al. Preoperative platelet to lymphocyte and neutrophil to lymphocyte ratios are independent prognostic factors for patients undergoing lung cancer radical surgery: a single institutional cohort study. Oncotarget. 2017;8:35301-10.

21. El Asmar A, Ghabi E, Saber T, Abou-Malhab C, Akl B, El Rassi Z. Plateletto-lymphocyte ratio is correlated with a delay in feeding resumption following a transhiatal esophagectomy with cervical anastomosis. World J Surg Oncol. 2020;18:1-7.

22. Mori M, Shuto K, Hirano A, Narushima K, Kosugi C, Yamazaki M, et al. Preoperative neutrophil-to-lymphocyte ratio may predict postoperative pneumonia in stage I-III gastric cancer patients after curative gastrectomy: a retrospective study. World J Surg. 2021;45:3359-69.

23. Dindo D, Demartines N, Clavien PA. Classification of surgical complications: a new proposal with evaluation in a cohort of 6336 patients and results of a survey. Ann Surg. 2004;240:205-13.

24. Akobeng AK. Understanding diagnostic tests 3: receiver operating characteristic curves. Acta Paediatr. 2007:96:644-7.

25. Shindoh J, Niwa H, Kawai K, Ohata K, Ishihara Y, Takabayashi N, et al. Predictive factors for negative outcomes in initial non-operative management of suspected appendicitis. J Gastrointest Surg. 2010;14:309-14.

26. Loftus TJ, Brakenridge SC, Croft CA, Smith RS, Efron PA, Moore FA, et al. Successful nonoperative management of uncomplicated appendicitis: predictors and outcomes. J Surg Res. 2018;222:212-8.

27. Kobayashi T, Hidaka E, Koganezawa I, Nakagawa M, Yokozuka K, Ochiai $\mathrm{S}$, et al. Prediction model for failure of nonoperative management of uncomplicated appendicitis in adults. World J Surg. 2021;45:3041-7.

28. Kim SH, Park SJ, Park YY, Choi SI. Delayed appendectomy is safe in patients with acute nonperforated appendicitis. Int Surg. 2015;100:1004-10.

29. van Dijk ST, van Dijk AH, Dijkgraaf MG, Boermeester MA. Meta-analysis of in-hospital delay before surgery as a risk factor for complications in patients with acute appendicitis. Br J Surg. 2018;105:933-45.

30. Faiz O, Clark J, Brown T, Bottle A, Antoniou A, Farrands P, et al. Traditional and laparoscopic appendectomy in adults: outcomes in English NHS hospitals between 1996 and 2006. Ann Surg. 2008;248:800-6.

31. Nakhamiyayev V, Galldin L, Chiarello M, Lumba A, Gorecki PJ. Laparoscopic appendectomy is the preferred approach for appendicitis: a retrospective review of two practice patterns. Surg Endos. 2010;24:859-64.

32. Yu MC, Feng YJ, Wang W, Fan W, Cheng HT, Xu J. Is laparoscopic appendectomy feasible for complicated appendicitis? A systematic review and meta-analysis. Int J Surg. 2017;40:187-97.

33. Lidar Z, Kuriansky J, Rosin D, Shabtai M, Ayalon A. Laparoscopic interval appendectomy for periappendicular abscess. Surg Endosc. 2000;14:764-6.

34. Tannoury J, Bassam A. Treatment options of inflammatory appendiceal masses in adults. World J Gastroenterol. 2013;19:3942-50.

35. Varela ML, Mogildea M, Moreno I, Lopes A. Acute inflammation and metabolism. Inflammation. 2018;41:1115-27.

36. Rossaint J, Margraf A, Zarbock A. Role of platelets in leukocyte recruitment and resolution of inflammation. Front Immunol. 2018;9:2712.

\section{Publisher's Note}

Springer Nature remains neutral with regard to jurisdictional claims in published maps and institutional affiliations.

Ready to submit your research? Choose BMC and benefit from

- fast, convenient online submission

- thorough peer review by experienced researchers in your field

- rapid publication on acceptance

- support for research data, including large and complex data types

- gold Open Access which fosters wider collaboration and increased citations

- maximum visibility for your research: over $100 \mathrm{M}$ website views per year

At BMC, research is always in progress.

Learn more biomedcentral.com/submissions 